GISELLE GARCÍA-HÍPOLA

Universidad de Granada

DOI : 10.14746/rie.2021.15.4

ORCID: 0000-0002-7927-544X

JAVIER ANTÓN-MERINO

Universidad de Burgos

ORCID: 0000-0002-7915-1121

SERGIO PÉREZ-CASTAÑOS

Universidad de Burgos

ORCID: 0000-0002-7775-8632

\title{
The use of emotions in 2019 European Elections campaign materials
}

\section{Introduction}

Political propaganda is often made effective through materials employed by political parties in their electoral campaigns. These elements comprise a 'letter of presentation' of how parties present themselves to citizens. The precise materials used depend on each party and on how they segment the electorate to try to persuade them. In particular, emotions are increasingly being harnessed as parties seek to engage citizens more effectively and thus obtain better results at the polls (Yarchi et al., 2020).

In this context, this study analyses four fundamental questions that are considered relevant to determine how, when and by whom emotions are used in campaign materials. The research focuses on the 2019 European elections, following an analytical strategy that seeks to identify the materials used by the European Parliament's various political groups. The article addresses two main objectives. On the one hand, it will seek to test whether there are geographical differences among the 28 Member States in terms of the use of emotional, rational, negative, and humorous campaign materials. On the other, it will assess whether in the 2019 European elections the political parties encompassed by the radical populist right made greater use of advertising and election campaign elements that appeal to the emotions of the electorate compared to other types of political groups. For this purpose, the database of the European Elections Monitoring Center (EEMC) ${ }^{1}$ will be used, as it has conducted an analysis of election campaign materials in those elections. ${ }^{2}$ For this purpose, first a territorial assessment will be conducted, to identify any differences among European Union countries. Subsequently, these same issues will be examined based on political groups that comprise the European Parliament, paying special interest to those located on the radical popu-

${ }^{1}$ More information on the above-mentioned Project can be found at the following link: www. electionsmonitoringcenter.eu/.

${ }^{2}$ As will be detailed in the methodological section, the campaign material analysed includes posters, press advertising, television advertising and posts on the Facebook social network. 
list right, with the aim of verifying whether, as previous studies (Voss, 2009; Steffan, Venema, 2019) claim, these types of parties make more extensive use of materials that appeal to emotions.

As mentioned, the analysis will focus on three fundamental factors that will be replicated to study both geographical and political groups. First, the differentiation between how emotional content is used will be assessed. Specifically, theory indicates that populist radical right parties tend to appeal more directly to issues linked to voters' emotions rather than their rationality (Larsson, 2020a; Laubestein, Urban, 2019). The second and third parts of this analysis focus on two specific types of emotions; specifically, the second step seeks to identify which of this emotional content evokes negative feelings. The third and final part of the analysis seeks to examine which 'party families' make greater use of humorous content. This type of content also appeals to voters' feelings and, therefore, it is essential to know if there are differences in its use among the different political groups.

\section{Context and state of the art}

\subsection{The 2019 European elections}

In this context, one of the most widespread explanatory models to understand the European electoral processes follows the classic category of 'second-order elections' (Reif, Schmitt, 1980). The fact is that, in general, European elections are considered by citizens to be elections of lesser importance than other types of elections. This is mainly due to two factors. Firstly, citizens are alienated from these elections because they consider them to be complex, due in part to the difficulty in explaining how they the function. And secondly, voters generally believe that the electoral result impacts less on their daily lives, as the European Parliament's decisions and their consequences feel distant to them.

One illustration of this belief is that these types of elections have lower rates of participation. In the specific case of the 2019 European Elections, average participation at European level was 50.66\%, but figures varied significantly among the different countries that make up the Union; with a maximum of $88.47 \%$ in Belgium and minimums below $30 \%$ in countries such as Croatia (29.85\%), Slovenia (28.89\%), Slovakia (22.74\%) and the Czech Republic (28.72\%). Although turnout is one of the variables that explain why European elections are 'second-order elections', there are two other particularly relevant factors: the punishment of political parties in government and, therefore, the improvement of those parties holding third of forth position in electoral representation at national level (Reif, Schmitt, 1980). Additionally, we should add a fourth dimension related to the political parties' communicative behaviour in those electoral campaigns considered as 'second-order'. In those campaigns, the speeches tend to be nationalized and the presence of first order 'issue-voting' as well as leaders is generalized, to simplify the political reality and bring it closer to the voter (García-Hípola, 2014). 
Regarding the 2019 elections, various surveys established the growth of Eurosceptic parties ${ }^{3}$, to the point of them representing over a third of the total number of members in the European Parliament; however, the electoral results, once the count was finalized, have shown another more nuanced image (Pérez Castaños, García Rabadán, 2019). While the size of the European Parliament has been reduced from 751 to 705 seats $^{4}$ (following the exit of the United Kingdom (UK) from the European Union), it has been decided to comment on the original results, given that the UK participated in that electoral campaign, and its materials are codified.

Figure 1. Composition of the European Parliament after the 2019 elections

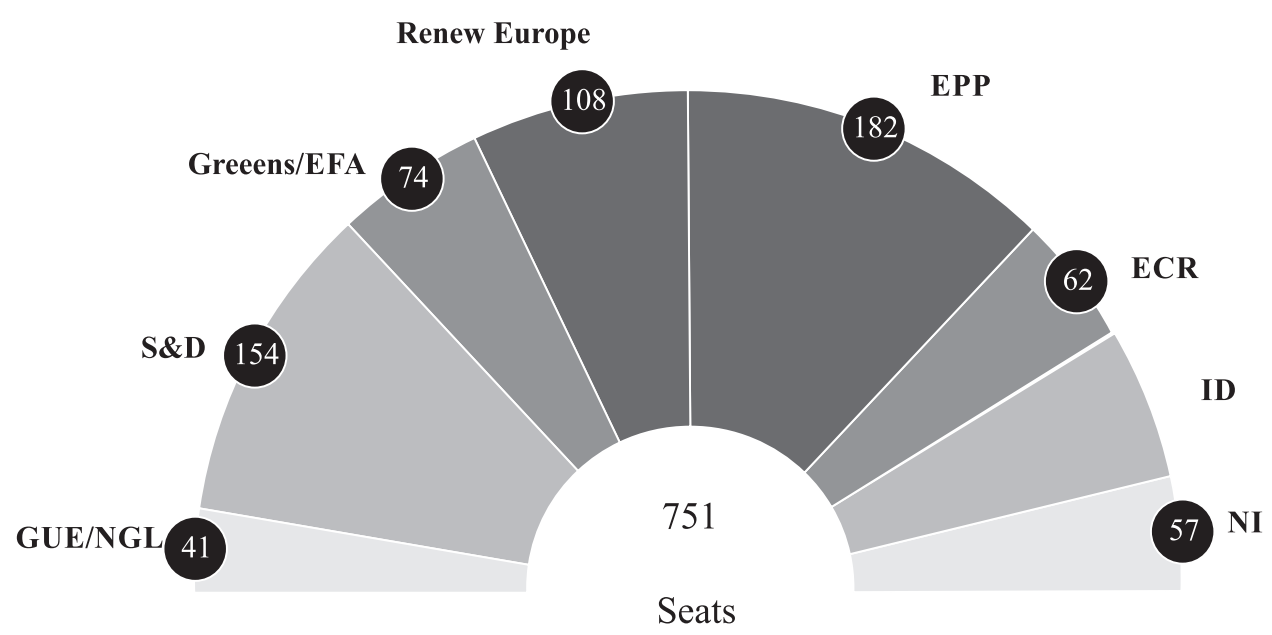

Source: European Parliament

Taking into consideration each political group as if it were a party, in 2019 there has been an increase in heterogeneity in Parliament, resulting in an effective number of Parliamentary Parties of $6.4^{5}$ (Laakso, Taagepera, 1979). Part of this growth can be explained by the rise in radical populist right-wing formations. The two main Community political groups are the European People's Party (EPP) and the Social Democrats (S\&D), which were unable to renew their traditional majority in Parliament, since they had to rely on the support of centre and green groups, to achieve the majority required to appoint the new Commission.

${ }^{3}$ It should be noted that not all Eurosceptic formations are related to right-wing populist parties. A deeper study of ideology and its influence on European Union politics can be found in Plaza-Colodro, Gómez-Reino \& Marcos-Marné (2018).

${ }^{4}$ For more information on changes in the composition of the European hemicycle, see the following link: https://www.europarl.europa.eu/news/en/press-room/20200130IPR71407/redistribution-of-seats-in-the-european-parliament-after-brexit.

5 To calculate this, we took every political group in the hemicycle, as a political party. Otherwise, the effective number of Parliamentary Parties rises to 65.7 parties. 
As for the Eurosceptics, in the 2014-2019 legislature the four groups totalled around 200 representatives, having increased by 21 over that time. The main current against the European project is represented by Identity and Democracy (ID), which is currently the fifth parliamentary force with 73 representatives, which comprises the main conservative Eurosceptic formations from countries such as Austria (FPÖ), Belgium (Vl. Belang), the Czech Republic (SPD), Germany (AfD), Denmark (DF), Estonia (EE), Finland (PS), Italy (LN) and France (RN). On the other hand, the other two families with Eurosceptic members (European Conservatives and Reformists -ECR- and Left Alliance -GUE/NGL-) have a more heterogeneous composition, while the members of ID have closed ranks against the European Union project.

\subsection{Political parties'campaign materials}

Traditionally, the works of Lazarfesfeld, Berelson \& Gaudet (1944), which lay the foundations for the study of electoral campaigns, define them as 'a planning and execution process of activities with the intention of winning votes'. Subsequently, numerous theoretical approaches have emerged that highlight, for example, how campaigns are communicative events where efforts are made to direct persuasive messages to an electorate, with the aim of increasing the maximum number of favourable votes (Schuster, 2020). By the 1990s, studies began appearing that alluded to the fact that campaigns seek to convince audiences to make one type of decision rather than another (Galais, Cardenal, 2017).

From this classical perspective, in addition to legitimising the process, electoral campaigns have configured a political and media landscape that has been called the "new campaign politics' (Pasquino, 2001), which, due to its novel condition, requires a new form of study in Political Science. This trend has led to what has been called the Americanization of politics (Hawley, 2019), which would fundamentally give prominence to the formats, styles, and techniques typical of political communication and political marketing in the United States; even through changes in content (McNair, 2003, p. 110).

One of the greatest examples of this political Americanization is reflected in the figure of the leader as a simplification of the political and electoral dynamics of presidential regimes, as well as in what we know as horse-race-campaigning (Reinemann, Wilke, 2007). This concept evidences an increasingly interpretative coverage of political issues based on game theory, with a logic of competition in which one wins at the expense of the other, and where emotions are very present in the construction of political messages. Thus, in this new method of electoral campaign communication that is spreading globally, the analysis of these campaigns acquires great importance. Special emphasis is placed on the study of all those elements that represent a change with respect to the previous way of proceeding.

In addition to this Americanization of politics, and therefore of electoral campaigns (Hawley, 2019), in this paper it is understood that such behaviour occurs in the context of what some have described as a growing prominence of emotions in campaigns. Specifically, to dynamise this consumption of emotions in political information, simplify it and make it easily accessible, 'infotainment' and the 'spectacularising' of politics 
are mixed; thereby establishing logics of spectacle and sensationalism (Nieland, 2008; Sayre, King, 2010; Schultz, 2012),

The consolidation of these dynamics, in general, represents a decisive and concerning step away from the more traditional processes of political socialisation and suggests the need for an analysis of emotions in the field of electoral campaigns, to evaluate how the leading political actors behave, and how they develop their campaign materials. This issue has numerous implications for democracy, as it can potentially jeopardise the stability of systems and even social coexistence itself (Mudde, 2004).

'Political propaganda' began to be used as a term around the 1960 s, so it can be considered a classic resource in the tools of electoral campaigns (Kadir et al., 2020). That is why, in the present work, it is understood that campaign materials are framed within the context of electoral propaganda, in which those in charge of spreading ideas do so in the style of political marketing (Wirz et al., 2018), and where all the communicative activities are integrated into a single strategy with clearly defined objectives.

Since the late 1990s, digital tools have been commonly employed to support traditional elements of electoral campaigning (Lusoli et al., 2002). These tools have been shaped in their form, content, and mode of use by political formations and have become a major campaign element (Steffan, Venema, 2020). On the other hand, with the emergence of the internet as an element for the development of the electoral campaign, the use of materials with negative and/or humorous content has been increasing (Duncombe, 2019). This process has been even more pronounced with the entry onto the scene of political parties referred to as the 'populist radical right' (Kishishita, 2018; Prodobnick et al. 2019), and their habitual recourse to what some authors have termed 'LOLitics' (Klein, 2019).

Many differences can be seen, not only in technical terms, with the use of digital tools and specifically the internet, but also in terms of discourse, where the emergence of new conceptual frameworks dominated by emotions can be observed. An example of this is the relevance acquired by what is known as negative advertising, which potentially increases political attention and support (Wallsten, 2011, p. 96). This negative advertising or attack advertising (Cassese, Holman, 2018) wears down adversaries by offering negative information about them. This negativity is now established as a classic feature of political advertising, fundamentally in the US (Kaid, Holtz-Bacha, 2006), and reinforces the concept of Americanization to which we alluded earlier.

Studies on the link between negative campaigning and the use of humour in electoral processes have their origin in the middle of the last century and have been gaining relevance, first in electoral campaigns in the US and, subsequently in the rest of the world (Tsichla et al., 2019). In fact, every relevant study carried out has coincided in identifying the use of humorous content as a formative element of negative campaigning to the extent that, both seek to stimulate a negative image of the opponent (Becker, 2012). This type of negative content seeks to appeal to fears, such that the opponent is seen as a threat and, as a counterpoint, the candidate who carries out the negative campaign is the source of the solution to the problems highlighted (Verhulshdonk, 2018; Tsatsanis et al., 2021). These effects are replicated in campaigns that use humour to ridicule the opponent; however, humour can also be oriented towards the presentation of a candidacy that may be more distant to the public (Verhulshdonk, 2018). 


\section{Methodology}

As stated, this article has two objectives. The first, more general, seeks to test whether there are geographical differences in the 28 Member States regarding the use of emotional, rational, negative, and humorous campaign materials. The second, more exhaustive, results in establishing the existence of differences in the use of emotional campaign content in the 2019 European Elections among political groups and political formations that contested these elections (Ganesh, 2020).

The first objective seeks to provide the research with a contextual image by country and, given the theory, it is not expected to find a differential trend by geographical area. However, the second objective needs to be subdivided into two working hypotheses. The first of these seeks to establish whether, as the theory states, there is greater use of negative materials by those political groups holding right-wing political parties in general and radical populist right-wing political formations (Winter, 2019; Larsson, 2020b). The second hypothesis, also in line with the theory detailed above, suggests that humorous content will also be more widely used by radical right-wing formations (Lamerichs et al., 2018; Forscher, Kteily, 2020).

To be able to test the hypotheses, the first thing that must be established is what is understood by the terms 'advertising' and 'electoral campaign'. Since the analysis was carried out from EEMC data, it is important to state that for the analysis of the 2019 electoral campaign the following elements have been taken into consideration: 'printed (posters and press advertising); political commercials (broadcast on TV or in public spaces); and social media content (Facebook)' (Novelli, Johansson, 2019, p. 8). Thus, the material to be analysed includes billboards, electoral advertising - in video and press format - and content on the social network Facebook ${ }^{6}$ (Larsson, 2020a). For its coding, different codebooks have been used to provide accurate content analysis, establish common and specific variables for each type of content and to explore verbal and visual dimensions through a mixed methodology. ${ }^{7}$

When conducting the analysis, different classifications have been employed. The first is that within emotionality ${ }^{8}$ we have included various categories such as: fun, feeling good and enthusiasm; empathy, compassion, and solidarity; pride, membership, and ambition; fear, threat, and insecurity; and finally, anger, disgust, and hatred (Novelli, Johansson, 2021). The second categorisation is what enter under the 'negative' and the 'humour' categories. From the overall disclaimed emotions, only fear, threat, and insecurity; and finally, anger, disgust, and hatred are selected as negative. Under the humoristic content category, the materials coded included jokes or any kind of references making fun of countries, political leaders, society, or groups different from those disseminating the party propaganda.

The next step, once the units of measurement have been clarified, is to establish the actors that can be categorised under the epithet 'radical populist right'. To this end,

${ }^{6}$ In this context, the EEMC analysed a total of 901 posters, 95 press ads, 11,485 social media posts and $477 \mathrm{TV}$ ads during the 2019 European election campaign.

7 The complete codebook can be found in Novelli \& Johansson (2019, p. 270.).

${ }^{8}$ However, despite this emotional coding, there are two further categorisations made by the EEMC team - neutral and rational content-. However, this content is not included in this analysis, as it only focuses on emotional elements. 
García-Hípola \& Pérez Castaños (2021, p. 26) identify some of the characteristics that need to be examined when establishing which parties fit into this category. Given that these formations are also detailed in the contextual section of this research, it has not been considered relevant to repeat them; however, because of this previous analysis, it has been decided to select a particular political formation in the European Parliament to focus on. Thus, since the bulk of the formations included in the radical populist right category are in the political group ID, this will be taken as a reference to verify the proposed objective.

Finally, to be able to respond to the hypotheses put forward, it should be noted that a descriptive comparative analysis is carried out using quantitative techniques. In this way, through a spatial representation for the first objective, and a comparative analysis between political groups for the second, it will be possible to verify whether the hypotheses outlined in the theory are proven.

\section{Results}

The first approach will be made in general terms, showing the use by country of emotional and rational content. Subsequently, the text will focus on the emotional part and, more specifically, the use of negative and humorous content will be disaggregated

Figure 2. Use of emotional content in EU countries

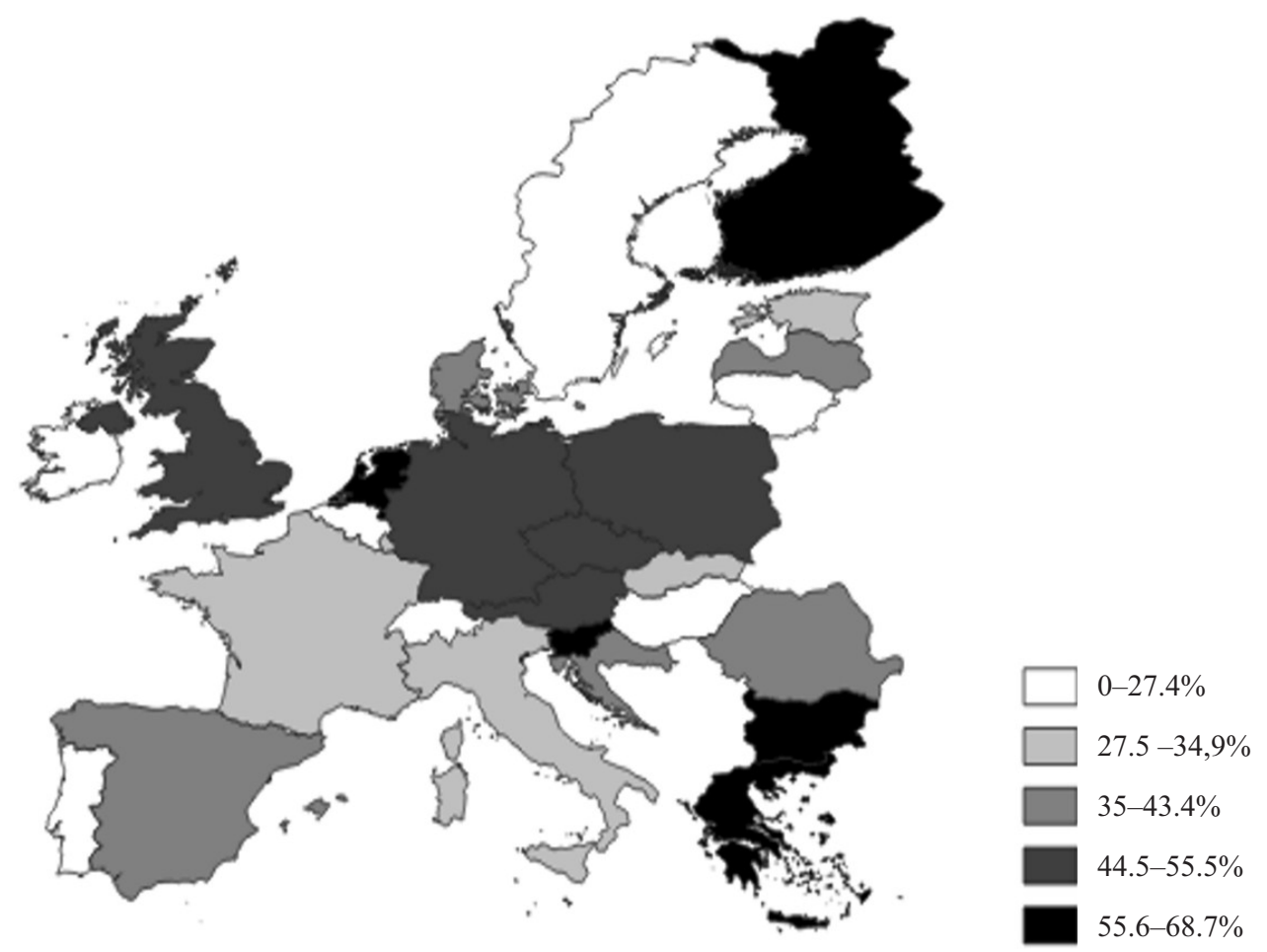

Source: Own elaboration with data from the EEMC. 
for each of the countries where information was collected in the aforementioned project. For this purpose, figures 2 to 4 illustrate the presence in the European Union of emotional, negative, and humorous content in the context of the election campaign for the 2019 European Parliament.

As can be seen, it is political parties in Central European countries that make the most extensive use of emotional elements in their campaign materials. Next, we find other countries not geographically related to each other. We see that Greece, Bulgaria, the Netherlands, Slovenia, and Finland are among the countries with the greatest use of emotional campaigning, together with the UK. On the opposite side we find Portugal, Sweden, Lithuania, Hungary, Belgium, and Ireland as the countries that use - in general terms - less emotional content in election campaign materials. Spain is in the middle, with a percentage of analysed materials appealing to the emotionality of voters between $35 \%$ and $43 \%$.

\section{Figure 3. Use of negative content in EU countries}

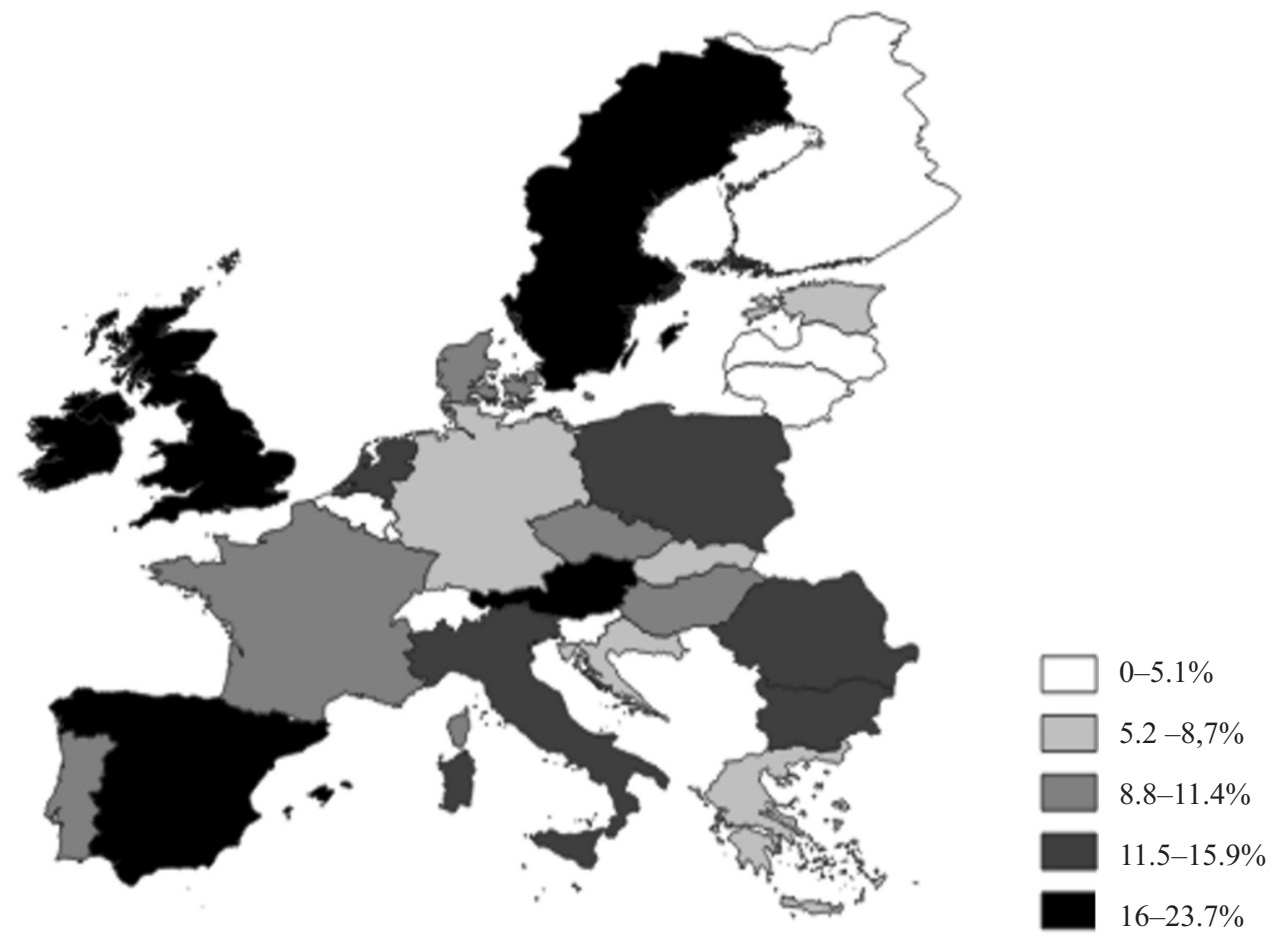

Source: Own elaboration with data from the EEMC.

Figure 3 shows the distribution of campaign materials with negative content. The use of this type of material is low, since the maximum values range from $16 \%$ to less than $24 \%$, meaning that Spain, Austria, Sweden, the UK, and Ireland are the countries with the highest use of negative content. At the opposite pole is Finland together with the Baltic countries, Belgium, and Luxembourg. Once again, we are unable to identify geographical trends, which suggests that the presence of radical right-wing populist 
parties across territories may be influencing the use of this type of material and that its use may be associated with them.

Figure 4, on the other hand, identifies the use of humorous content. The percentages are again reduced, with less than $10 \%$ of the materials analysed being categorised under this heading for each country. Thus, the countries with the greatest use of humorous content are once again those of Central Europe (Germany, Austria, and the Czech Republic), followed by Bulgaria. Close behind are Italy, Poland, the UK, and Sweden, with more than $1 \%$ of materials that can be included in this category. The other countries use less than $1 \%$ of materials related to the category of humorous advertising, denoting, once again, a generalised absence, whether using humour against a political adversary or opting to laugh at oneself.

Figure 4. Use of humorous content in EU countries

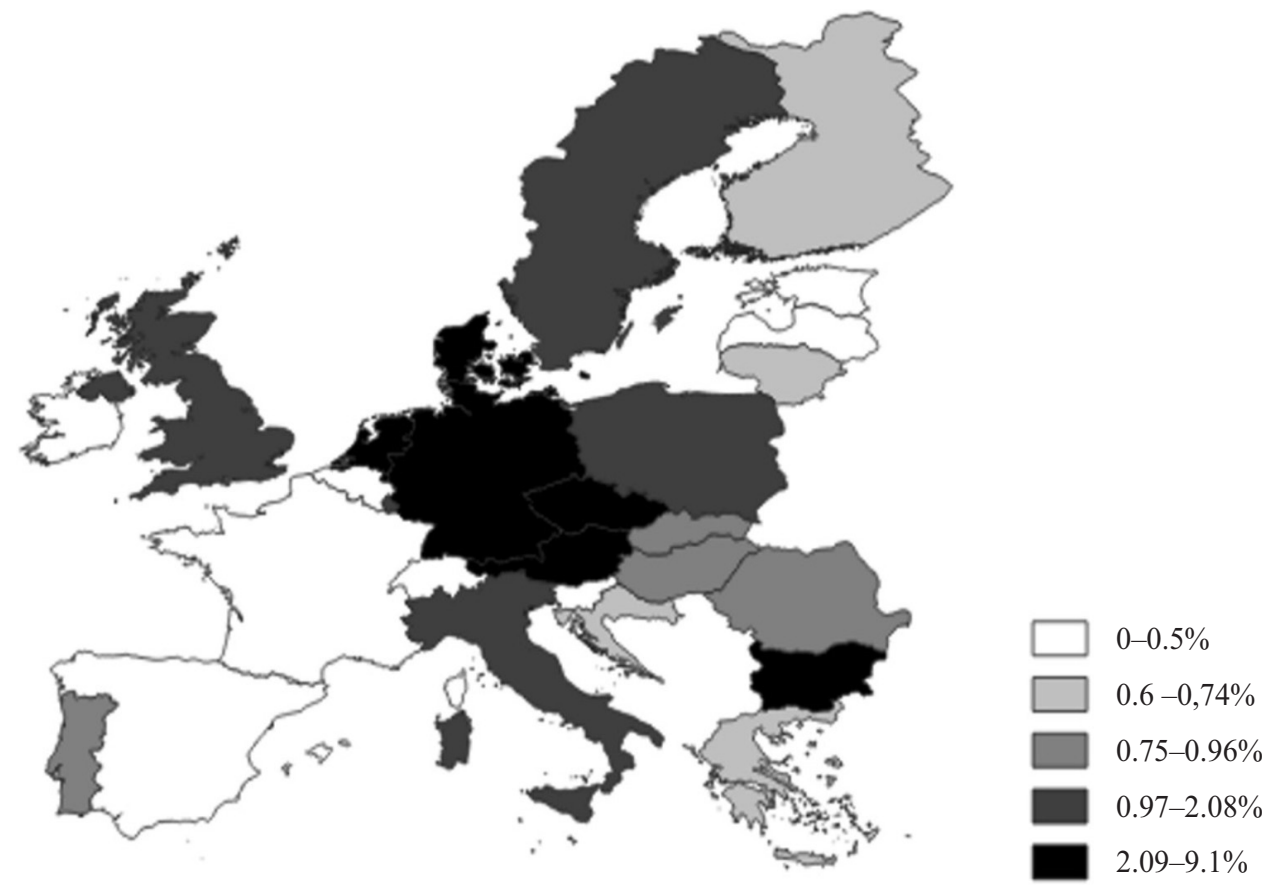

Source: Own elaboration with data from the EEMC.

Following this initial analysis, Figures 5 to 7 relate to the families of parties that make up the European Parliament. Figure 5 deals with the percentage of the content of the analysed campaigns that appeal to emotions, based on each of the European Parliament's political groups.

Beginning with the analysis of Figure 5, we must point out that, as has been suggested in the theoretical framework, political parties of a more radical populist nature, mainly included in the political groups ID and the ECR, make more extensive use of content that appeal to voters' emotional side. Almost $60 \%$ of ID's content employs this element, making them by far the group that recurs to emotions the most. On the 
other hand, in the group of the unidentified, there are also some formations that share similarities with those of the populist radical right. Although the differences between the ECR and the GUE/NGL are very small, all within a range of five percentage points; the other formations remain stable at between 30 and $40 \%$.

What the data reflected in Figure 5 denote is that appealing to electors' emotionality seems to be a generalised pattern in current electoral contests (Ducombe, 2019). Thus, we see how the political groups in the European Parliament linked to the radical populist right seek to appeal to emotionality in a broader way than the classical or traditional formations (Tsichla et al., 2019).

Figure 5. Use of emotional content by European political group

$70 \%$

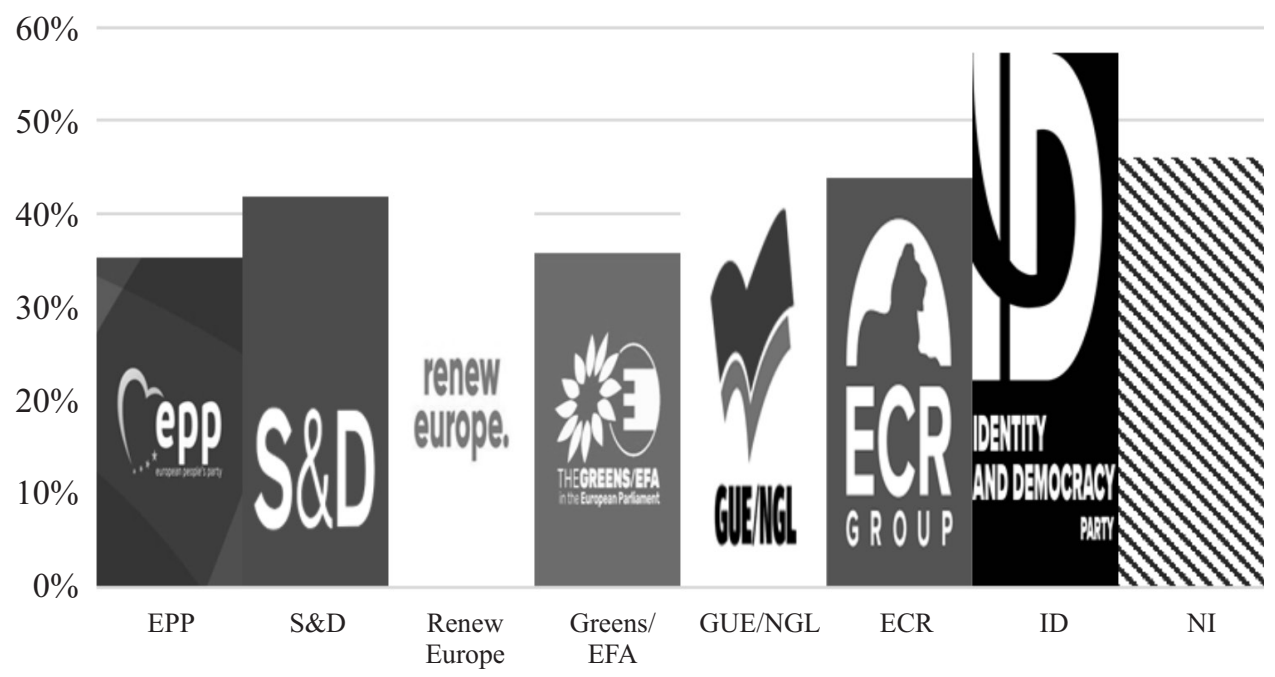

Source: Own elaboration with data from the EEMC.

Figure 6 shows the use of negative campaigning by the different political groups in the European Parliament. We can observe how the Non-Aligned group makes the most extensive use of this type of material. Once again, the groups including right-wing populist parties use this content on a regular basis and do so significantly more than the groups including traditional political parties. Thus, the ECR's use of negative content is almost at $20 \%$, while ID employs negative messages in around $18 \%$ of the campaign content analysed; compared to less than $10 \%$ by the other parliamentary groups.

The last of the Figures under analysis deals with the use of humorous or satirical content in the 2019 European campaign. In this case, none of the analysed political groups exceeds $2 \%$ of materials included under this category. However, we find for the first time a trend that differs from the pattern suggested by the theory, and which shows the Greens using the most humorous materials, along with the ECR. In third position is ID, with just under $2 \%$ of materials in this category. As for the other political groups, 
the deployment of humorous or satirical materials is minimal; not exceeding $1 \%$ of the total number of elements analysed.

Figure 6. Use of negative publicity by European political group

$25 \%$

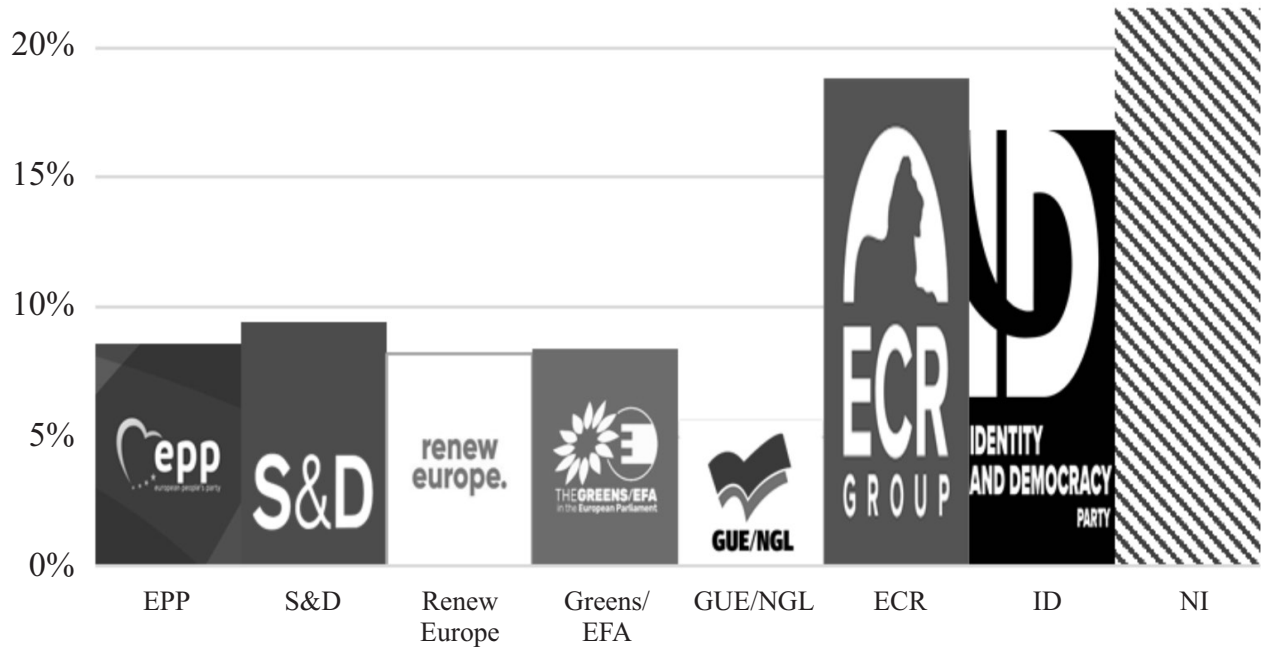

Source: Own elaboration with data from the EEMC.

Figure 7. Use of humorous advertising by European political group

$2.5 \%$

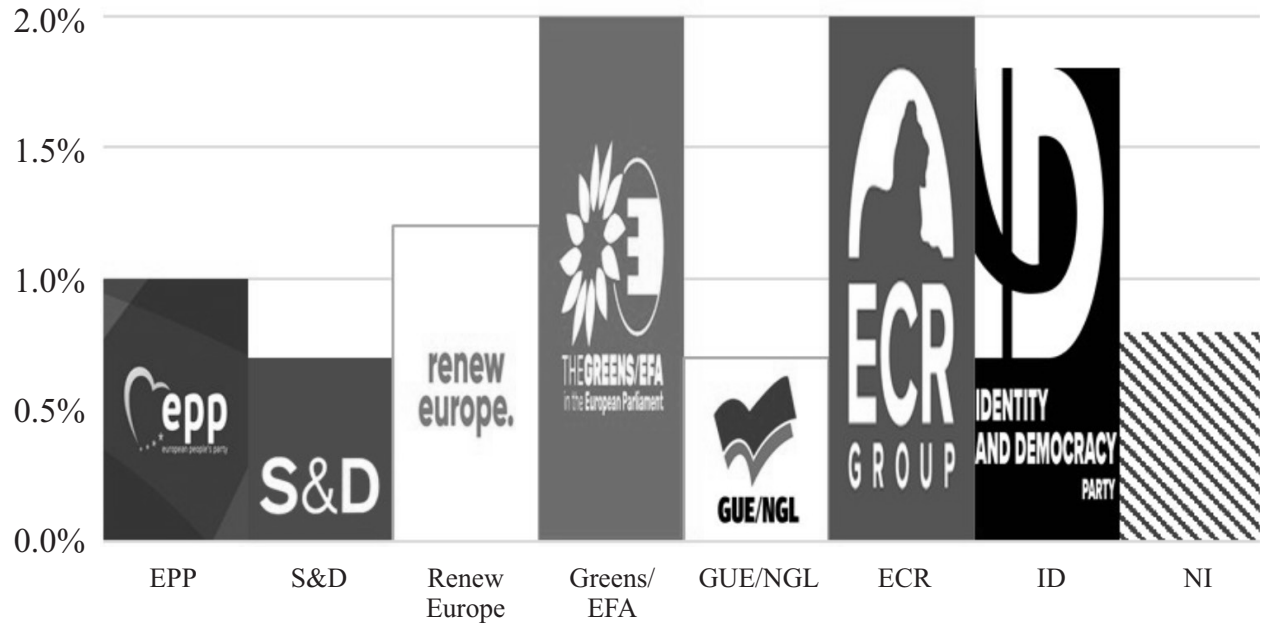

Source: Own elaboration with data from the EEMC. 


\section{Discussion}

Electoral campaigns are therefore the scenario in which electoral propaganda is developed in the form of different materials (Herrero, 2019). Such political propaganda mixes with elements of informative and persuasive communication, where speeches are written and disseminated with the intention of ideological persuasion (Vasilopoulou, Wagner, 2017), and where suggestion is one of the most important factors. In this sense, suggestion is the main psychological element of propaganda (Schuster, 2020). Thus, while in any other electoral campaign environment the personal characteristics of the candidates are irrelevant, in the case of electoral propaganda they become central (Garzia, Ferreira da Silva, 2021). Therefore, the political and electoral propaganda context in which campaign materials are used are the perfect scenario to make use of emotions.

Emotions are a central element in any political regime because they can politically mobilize citizens and activate electoral participation (Arias, 2016). Thus, it is understood that politics is a scenario in which there is a combination between reason and emotion and where the latter almost always takes precedence (Westen, 2007), among other things because we tend to remember things based on the emotion we have felt. In relation to this, emotions play a fundamental role in the elaboration of political strategies and democracy is a political regime based on opinions sustained upon emotions (Arias, 2016).

As explained above, Europe has a specific political context in which electoral campaigns are developed. That same context makes it possible for the different political parties to allow themselves some unorthodox strategies when using tactics and strategies in their campaign materials. Thus, the political propaganda and materials used during the campaign for the 2019 European elections are a good example of this.

The objective of this research was to identify whether radical right-wing populist political parties made greater use of advertising and electoral campaign elements that appealed to the electorate's emotionality, instead of seeking to engage their rationality. To this end, a general geographic analysis was carried out to identify existing differences between countries to understand, deductively, whether in those countries where these formations are stronger, the use of this type of content is greater. In fact, the data show that rationality, ideas, and argumentation are increasingly renounced in favour of generalities, scenography and emotional appeals that stimulate voters (Wolton, 2005). Exactly as the theory predicted, the concentration on issues related to emotions occurs in a transversal way, geographically speaking, regardless of whether there are right-wing populist parties in each country or not.

This first analysis has made it possible to draw up a satisfactory state of the art, helping to unravel the existing differences between the various political groups in the European hemicycle. Thus, thanks to the current structure of the European Parliament, we have segmented the analysis into the eight major political groups represented, three of which have political formations that can be classified under the label of right-wing populist parties. These are the ECR, ID and several others that are not listed in any 
other group. Thus, regarding the use of emotions, it has been shown that all political formations try to appeal more to the feelings of the electorate, connecting with the theoretical proposals about the Americanization of politics and the use of a greater emotional content in electoral campaigns (Hawley, 2019; Nieland, 2008; Schultz, 2012). This trend is even more striking in the political groups mentioned above, as they make the most extensive use of these issues, as previous studies predicted (Voss, 2009; Steffan, Venema, 2019).

Again, hand in hand with the theory, this Americanization combined with the higher penetration of the internet and its usage through, for example, social media, led to a growing prominence of both negative content (Ducombe, 2019). The analysis of the use of negative campaigning has again denoted more extensive use of these issues in the analysed campaign materials for the formations included in the European groups of the ECR, ID and those that are not listed. The differences in terms of negative content are ostensible among political groups. If we focus on humoristic content, we can see a small deviance from the theory, as it predicted a higher presence in those political groups that include right-wing populist parties (Klein, 2019; Prodobnick et alt., 2019) and due to the Americanization of politics (Cassese, Holman, 2018). Data showed that neither is it extensively used across countries, nor among political groups. In this sense, and again counterintuitive with the theoretical proposals, analysed data show an increase in the use of humoristic content by the Greens; although, as mentioned, appealing to humour is not a common technique.

\section{Conclusions}

As stated, political propaganda is articulated around electoral campaigns, which is why this is the appropriate context to analyse its use by different parties or political groups. Thus, thanks to the work carried out by the EEMC, we have been able to conduct this comparative analysis that has proved almost all our hypotheses to be correct.

We have been able to verify how the use of negative content during the election campaign is broadly employed in the 28 countries that were part of the 2019 European Parliamentary elections. Similarly, materials containing humorous elements, although rarely used, tend to be employed by the countries of so-called continental Europe and not so much by Mediterranean countries.

In sum, we can conclude this research by affirming that those parties that might be labelled as right-wing populist have used content that appeals to the emotions and feelings of the electorate on a more regular basis. In this line, and even though the European electoral context should be analysed in a differentiated manner due to its exceptional characteristics, it should be noted that it seems to follow a similar dynamic to that of other national or subnational electoral contexts. In this sense, this analysis opens the door to more in-depth research regarding the feelings that these parties are trying to appeal to, or the differences that may exist among right-wing populist parties or other formations that share a political group with them in the European Parliament. 


\section{Bibliography}

Arias M. (2016), La democracia sentimental. Política y emociones en el siglo XXI, Página indómita, Barcelona.

Becker A. (2012), Comedy Types and Political Campaigns: The Differential Influence of Other-Directed Hostile Humor and Self-Ridicule on Candidate Evaluations, "Mass Communication and Society", vol. 15, no. 6, pp. 791-812.

Boulianne S., Koc-Michalska K., Bimber B. (2020), Right-wing populism, social media and echo chambers in Western democracies, "New Media \& Society", vol. 22, no. 4, pp. 683-699.

Cassese E. C., Holman M. R. (2018), Party and Gender Stereotypes in Campaign Attacks, "Political Behaviour", no. 40, pp. 785-807.

Castells M. (2011), The Rise of the Network Society: The Information Age: Economy, Society, and Culture (Vol. 1), John Wiley \& Sons, London.

Deseriis M. (2020), Two variants of the Digital Party. The Platform Party and The Networked Party, "Partecipazione e Conflitto", vol. 13, no. 1, pp. 896-917.

Duncombe C. (2019), The Politics of Twitter: Emotions and the Power of Social Media, "International Political Sociology", vol. 13, no. 4, pp. 409-429.

Forscher P. S., Nour S. K. (2020), A Psychological Profile of the Alt-Right, "Perspectives on Psychological Science", vol. 15, no. 1, pp. 90-116.

Galais C., Cardenal A. (2017), When David and Goliath campaign online: The effects of digital media use during electoral campaigns on vote for small parties, "Journal of Information Technology \& Politics", vol. 14, pp. 372-386.

Ganesh B. (2020), Weaponizing white thymos: flows of rage in the online audiences of the alt-right, "Cultural Studies", vol. 34, no. 6, pp. 892-924.

García Hípola G. (2014), Estrategias de comunicación política en contextos concurrenciales: las campañas electorales de 2008 y 2012 en Andalucía, Editorial Universidad de Granada, Granada.

García Hípola G., Pérez Castaños S. (2021), Las emociones como estrategia de comunicación en las elecciones europeas de 2019: VOX, "Más Poder Local", vol. 43, pp. 20-27.

Garzia D., Ferreira da Silva F. (2021), Negative personalization and voting behavior in 14 parliamentary democracies, 1961-2018, "Electoral Studies", vol. 71, 102300.

Gerbaudo P. (2019), The Platform Party: The Transformation of Political Organisation in the Era of Big Data, in: Digital Objects, Digital Subjects: Interdisciplinary Perspectives on Capitalism, Labour and Politics in the Age of Big Data, eds. D. Chandler, C. Fuchs, University of Westminster Press, Westminster.

Hawley G. (2019), The Alt-Right. What everyone needs to know, Oxford University Press, Oxford.

Herrero J. C. (2019), Manual de marketing político, Almuzara, Córdoba.

Kadir S., Lokman A., Tsuchiya T., Shuhidan S. M. (2020), Analysing Implicit Emotion and Unity in Propaganda Videos Posted in Social Network, "Journal of Physics: Conference Series", vol. 1529 , pp. 1-12.

Kaid L. L., Holtz-Bacha C. (2006), Television Advertising and Democratic Systems Around the World: A Comparison of Videostyle Content and Effects, in: eds. L. L. Kaid, C. Holtz-Bacha, Political Advertising in Western Democracies, Thousand Oaks, London.

Kishishita D. (2018), Emergence of populism under ambiguity, "International Tax and Public Finance", vol. 25, pp. 1559-1562.

Klein O. (2019), LOLitics. The content and impact of Dutch populist Internet memes, Available in SSRN, http://dx.doi.org/10.2139/ssrn.3371224.

Laakso M., Taagepera R. (1979), Effective Number of Parties. A Measure with Application to West Europe, "Comparative Political Studies", vol. 12, no. 1, pp. 3-27. 
Lamerichs N., Nguyen D., Puerta Melguizo M. C., Radojevic R. (2018), Elite Male Bodies: The Circulation of Alt-Right Memes and The Framing of Politicians on Social Media, "Participations. Journal of Audiences \& Reception Studies", vol. 15, no. 1, pp. 180-206.

Larsson A. O. (2020b), Facebook as a 'Trusted Space of Everyday Communication': Parties, Citizens and Direct Representation, "Journal of Applied Journalism \& Media Studies", vol. 9, no. 2, pp. 127-146.

Larsson A. O. (2020a), Right-wingers on the rise online: Insights from the 2018 Swedish elections, "New Media and Society", vol. 22, no. 12, pp. 2108-2127.

Laubestein S., Urban A. (2019), Case studies: which types of campaign against hate and extremism on the internet work, which do not, and why?, in: Hate Speech and Radicalisation Online: The OCCI Research Report, eds. J. Baldauf, J. Ebner, J. Guhl, ISD, London.

Lazarsfeld H. P., Berelson B., Gaudet H. (1944), The People's Choice, Columbia University Press, New York.

Lilleker D. G., Jackson N. A. (2010), Toward a More Participatory Style of Election Campaigning: The Impact of Web 2.0 on the UK 2010 General Election, "Policy \& Internet", vol. 3, pp. 69-98.

Lioy A., Del Valle M., Gottlieb J. (2019), Platform politics: Party organisation in the digital age, "Information Polity", vol. 24, no. 1, pp. 41-58.

Lusoli W., Ward S., Gibson R. (2002), Political organisations and online mobilisation: Different media-same outcomes?, "New Review of Information Networking", vol. 8, no. 1, pp. 89-107.

Marcus G. E., MacKuen M. B. (2004), Anxiety, Enthusiasm, and the Vote: The Emotional Underpinnings of Learning and Involvement During Presidential Campaigns, in: Political Psychology: Key Readings, eds. J. T. Jost, J. Sidanius, Psychology Press, New York.

Martínez F. (2008), “Por qué importan las campañas electorales?”, Centro de Investigaciones Sociológicas, Madrid.

McNair B. (2003), An Introduction to Political Communication, Routledge, London.

Montero J. R., Gunther R. (2003), The Literature on Political Parties: a Critical Reassessment, "ICPS Working Papers", vol. 219.

Mudde C. (2004), The Populist Zeitgeist, “Government and Opposition” vol. 39, no. 4, pp. 541-563.

Muñoz-Alonso A., Rospir J. I. (1999), Democracia mediática y campañas electorales, Ariel, Barcelona.

Nieland J. (2008), Politainment, in: The international encyclopedia of communication, ed. W. Donsbach, Blackwell Publishing, Oxford.

Novelli E., Johansson B. (2019), 2019 European Elections Campaign: Images, Topics and Media in the 28 Member States, European Union, Brussels.

Pasquino G. (2001), The New Campaign Politics in Southern Europe, in: Parties, Politics and Democracy in the New Southern Europe, eds. N. Diamandouros, R. Gunther, John Hopkins University, London.

Pérez Castaños S., García Rabadán J. (2019), El pinchazo de los partidos antieuropeos, "The conversation", https://theconversation.com/el-pinchazo-de-los-partidos-antieuropeos-118715, 01.07.2019.

Plaza-Colodro C., Gómez-Reino M., Marcos-Marné H. (2018), Does host ideology shape populist parties' attitudes towards the EU? The links of populism and Euroscepticism in Southern Europe, "Revista Internacional de Sociología", no. 76, vol. 4, e112.

Prodobnik B., Skreblin Kirbis I., Koprcina M., Stanley H. E. (2019), Emergence of the unified rightand left-wing populism - When radical societal changes become more important than ideology, "Physica A: Statistical Mechanics and its Applications", vol. 517, pp. 459-474.

Reinemann C., Wilke J. (2007), It's the Debates, Stupid! How the Introduction of Televised Debates Changed the Portrayal of Chancellor Candidates in the German Press, 1949-2005, "Press/ Politics", no. 12, pp. 92-111. 
Ruiz-Rufino R. (2012), Los sistemas electorales de la Unión Europea y sus consecuencias políticas, in: M. Torcal, J. Font, Elecciones europeas 2009, CIS, Madrid.

Savre S., King C. (2010), Entertainment and society: influences, impacts and innovations, Routledge, New York.

Schultz D. (2012), Politainment, the ten rules of contemporary politics: a citizens' guide to understanding campaigns and elections, Theoklesia, WI.

Schuster C. (2020), Patrons against clients: Electoral uncertainty and bureaucratic tenure in politicized states, "Regulation and Governance", vol. 14, no. 1, pp. 26-43.

Steffan D., Venema N. (2019), Personalised, de-ideologised and negative? A longitudinal analysis of campaign posters for German Bundestag elections, 1949-2017, "European Journal of Communication", vol. 34, no. 3, pp. 267-285.

Steffan D., Venema N. (2020), New medium, old strategies? Comparing online and traditional campaign posters for German Bundestag elections, 2013-2017, "European Journal of Communication", vol. 35, no. 4, pp. 370-380.

Tsatsanis E., Terperoglou E., Seriatos A. (2020), Two-partyism Reloaded: Polarisation, Negative Partisanship, and the Return of the Left-right Divide in the Greek Elections of 2019, "South European Society and Politics", DOI: 10.1080/13608746.2020.1855798.

Tsichla E. et al. (2019), Greek political advertising in retrospect: a longitudinal approach, "Communication Research Reports", vol. 36, no. 5, pp. 404-414.

Van Dijck J. (2013), The Culture of Connectivity: A Critical History of Social Media, Oxford University Press, New York.

Vasilopoulou S., Wagner M. (2017), Fear, anger and enthusiasm about the European Union: Effects of emotional reactions on public preferences towards European integration, "European Union Politics", vol. 18, no. 3, pp. 382-405.

Verhulsdonk I. (2018), The use of humor and negative campaigning. An (un)happy marriage?, University of Amsterdam, Amsterdam.

Voss K. (2009), Using humor in conjunction with negative consequences in advertising, "Journal of Current Issues and Research in Advertising”, vol. 31, no. 2, pp. 25-39.

Wallsten K. (2011), Many Sources, One Message: Political Blog Links to Online Videos During the 2008 Campaign, "Journal of Political Marketing", vol. 10, pp. 88-114.

Westen D. (2007), The political brain: The role of emotion in deciding the fate of the nation, Public Affairs, New York.

Winter A. (2019), Online Hate: From the Far-Right to the 'Alt-Right', and from the Margins to the Mainstream, in: Online Othering: Exploring violence and discrimination on the web, eds. K. Lumdsen, E. Harmer, Palgrave, London.

Wirz D., Wettstein M., Schulz A., Müller P., Schemer C., Ernst N., Esser F., Werner W. (2018), The Effects of Right-Wing Populist Communication on Emotions and Cognitions toward Immigrants, "International Journal of Press/Politics", vol. 23, no. 4, pp. 496-516.

Yarchi M., Baden C., Kigler-Vilenchik N. (2020), Political Polarization on the Digital Sphere: A Cross-platform, Over-time Analysis of Interactional, Positional, and Affective Polarization on Social Media, "Political Communication", vol. 38, no. 1-2, pp. 1-42.

\section{Summary}

This research analyses three fundamental questions to determine how, when and by whom emotions are used in campaign materials (political propaganda). Focusing on the 2019 European elections we carry out a three-phase analysis. Firstly, we check the use of rational content against content that appeals to voters' emotions. Secondly, we observe which of these emo- 
tions are channelled towards the use of negative strategies and, therefore, identifying who is the object of this attack. And lastly, we determine which party families make the most use of humorous content since this resource is believed to be part of an appeal to voter's feelings and, therefore, it is essential to know if there are differences between political groups. Considering this analytical strategy, the structure of the work begins with the contextualisation of the 2019 European elections to focus, later, on highlighting the importance of electoral campaigns as a given time when communicative activity intensifies. Once the importance of electoral campaigns has been defined the article analyses how campaign materials, in a general context of political propaganda, are one of the most powerful tools. In this sense, the analytical strategy of political parties' campaign materials can be said to focus on the use of emotions. Data from the European Elections Monitoring Center (EEMC) has been used not only for theoretical contextualization, but throughout the whole paper.

Key words: Emotions, Electoral Campaigns, Campaigns Materials, Elections, European Union

\section{Wykorzystanie emocji w materiałach kampanijnych na wybory europejskie 2019}

\section{Streszczenie}

Niniejsze badanie analizuje trzy podstawowe pytania mające na celu określenie jak, kiedy i przez kogo emocje są wykorzystywane w materiałach kampanijnych (propagandzie politycznej). W trakcie wyborów europejskich w 2019 roku przeprowadziliśmy analizę w trzech fazach. Po pierwsze, sprawdziliśmy wykorzystanie treści racjonalnych w zestawieniu z treściami odwołującymi się do emocji wyborców. Po drugie, obserwowaliśmy, które z tych emocji są ukierunkowane na stosowanie strategii negatywnych, a więc sprawdziliśmy, kto jest obiektem tego ataku. I wreszcie, określiliśmy, które rodziny partyjne w największym stopniu wykorzystują treści humorystyczne, ponieważ rozumiemy, że ten zasób jest częścią odwołania się do uczuć wyborcy i dlatego istotne jest, aby wiedzieć, czy istnieją różnice między grupami politycznymi. Uwzględniając tę strategię analityczną, struktura pracy rozpoczyna się od kontekstualizacji wyborów europejskich w 2019 roku, aby później skupić się na podkreśleniu znaczenia kampanii wyborczych jako okresu, w którym nasila się aktywność komunikacyjna. Po zdefiniowaniu i teoretycznym ograniczeniu znaczenia kampanii wyborczych, artykuł odnosi się do tego, w jaki sposób materiały kampanijne, w ogólnym kontekście propagandy politycznej, są jednym z najbardziej determinujących narzędzi. W tym sensie strategia analityczna dotycząca różnych materiałów kampanijnych wykorzystywanych przez partie polityczne koncentruje się wokół wykorzystania emocji. Dane pochodzące z Europejskiego Centrum Monitorowania Wyborów (EEMC) zostały wykorzystane nie tylko do kontekstualizacji teoretycznej, ale także w całym artykule.

Słowa kluczowe: emocje, kampanie wyborcze, materiały kampanijne, wybory, Unia Europejska 
tions are channelled towards the use of negative strategies and, therefore, identifying who is the object of this attack. And lastly, we determine which party families make the most use of humorous content since this resource is believed to be part of an appeal to voter's feelings and, therefore, it is essential to know if there are differences between political groups. Considering this analytical strategy, the structure of the work begins with the contextualisation of the 2019 European elections to focus, later, on highlighting the importance of electoral campaigns as a given time when communicative activity intensifies. Once the importance of electoral campaigns has been defined the article analyses how campaign materials, in a general context of political propaganda, are one of the most powerful tools. In this sense, the analytical strategy of political parties' campaign materials can be said to focus on the use of emotions. Data from the European Elections Monitoring Center (EEMC) has been used not only for theoretical contextualization, but throughout the whole paper.

Key words: Emotions, Electoral Campaigns, Campaigns Materials, Elections, European Union

\section{Wykorzystanie emocji w materiałach kampanijnych na wybory europejskie 2019}

\section{Streszczenie}

Niniejsze badanie analizuje trzy podstawowe pytania mające na celu określenie jak, kiedy i przez kogo emocje są wykorzystywane w materiałach kampanijnych (propagandzie politycznej). W trakcie wyborów europejskich w 2019 roku przeprowadziliśmy analizę w trzech fazach. Po pierwsze, sprawdziliśmy wykorzystanie treści racjonalnych w zestawieniu z treściami odwołującymi się do emocji wyborców. Po drugie, obserwowaliśmy, które z tych emocji są ukierunkowane na stosowanie strategii negatywnych, a więc sprawdziliśmy, kto jest obiektem tego ataku. I wreszcie, określiliśmy, które grupy polityczne w największym stopniu wykorzystują treści humorystyczne, ponieważ rozumiemy, że ten zasób jest częścią odwołania się do uczuć wyborcy i dlatego istotne jest, aby wiedzieć, czy istnieją różnice między grupami politycznymi. Uwzględniając tę strategię analityczną, struktura pracy rozpoczyna się od kontekstualizacji wyborów europejskich w 2019 roku, aby później skupić się na podkreśleniu znaczenia kampanii wyborczych jako okresu, w którym nasila się aktywność komunikacyjna. Po zdefiniowaniu i teoretycznym ograniczeniu znaczenia kampanii wyborczych, artykuł odnosi się do tego, w jaki sposób materiały kampanijne, w ogólnym kontekście propagandy politycznej, są jednym z najbardziej determinujących narzędzi. W tym sensie strategia analityczna dotycząca różnych materiałów kampanijnych wykorzystywanych przez partie polityczne koncentruje się wokół wykorzystania emocji. Dane pochodzące z Europejskiego Centrum Monitorowania Wyborów (EEMC) zostały wykorzystane nie tylko do kontekstualizacji teoretycznej, ale także w całym artykule.

Słowa kluczowe: emocje, kampanie wyborcze, materiały kampanijne, wybory, Unia Europejska 
